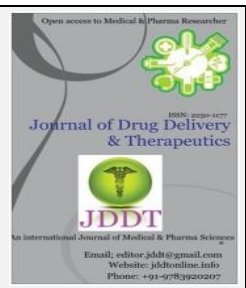

Open $\odot$ Access

Research Article

\title{
An Efficient, Green, Catalyst Free Synthesis and Crystallographic Study of Benzo-4H-Pyrans in Aqueous Medium
}

\section{S. Silambarasan *a, A. Jamal Abdul Nasser a}

a Department of Chemistry, Jamal Mohamed College, Tiruchirappalli 620020, Tamil Nadu, India.

\section{ABSTRACT}

A highly efficient and environmentally benign for the synthesis a of 2-amino-7-hydroxy-4-aryl-4H-chromene-3-carbonitrile derivatives (4a-n) in good to high yields (90\%-97\%) by one-pot three-component Michael addition reaction of malononitrile, aromatic aldehydes and resorcinol under reflux condition was developed in aqueous medium. Single crystal X-ray studies show that $4 \mathbf{h}$ crystallizes in the formula $\mathrm{C}_{22} \mathrm{H}_{15} \mathrm{Cl}_{2} \mathrm{~N}_{2} \mathrm{O}_{2}$ $M r=410.26$, Monoclinic, Space group $\mathrm{P} 2(1) / c, a=12.753(9) \AA, b=6.665(4) \AA, c=24.050(14) \AA, \beta=102.95(3) A^{\circ}$ and $4 \mathbf{i} C_{16} \mathrm{H}_{10} \mathrm{Cl}_{2} \mathrm{~N}_{2} \mathrm{O}_{2}, M r=333.16$, Triclinic, Space group P-1, a=6.271(3) $\AA, b=18.697(5) \AA, c=13.794(7) \AA, \beta=94.269(17) A^{\circ}$. The structure of the products were further confirmed by ${ }^{1} \mathrm{H}$ NMR, ${ }^{13} \mathrm{C}$ NMR, IR and Mass spectrum.

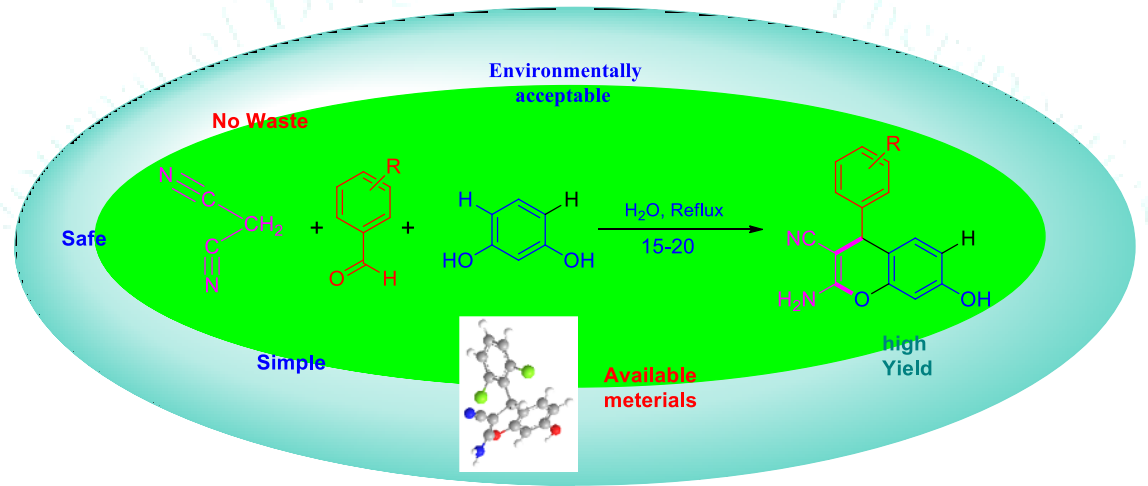

Keywords: Benzopyrans, malononitrile, resorcinol, Michael addition, water mediated synthesis, single crystal XRD

Article Info: Received 10 July 2019; Review Completed 21 Aug 2019; Accepted 26 Aug 2019; Available online 30 Aug 2019

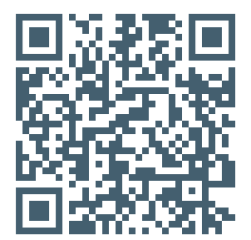

Cite this article as:

Silambarasan S, Abdul Nasser AJ, An Efficient, Green, Catalyst Free Synthesis and Crystallographic Study of Benzo - $4 \mathrm{H}$ Pyrans in Aqueous Medium, Journal of Drug Delivery and Therapeutics. 2019; 9(4-A):280-289

http://dx.doi.org/10.22270/jddt.v9i4-A.3418

S. Silambarasan, Department of Chemistry, Jamal Mohamed College, Tiruchirappalli 620020, Tamil Nadu, India.

\section{INTRODUCTION}

Pyran (chromene or benzo Pyran) is an oxygen-containing heterocyclic moiety, which is attracted great significance due to their medicinal application. The pyran ring is the core unit of benzopyran, chromone, flavanoids, coumarin etc., which exhibit different pharmacological activities. Pyran heterocycles are both prevalent across compounds classified as of 'natural origin' and 'man-made'. Numerous naturally occurring compounds containing pyrans and benzopyrans, show attractive therapeutic activities. The classification of pyran heterocyclic compounds depends on the presence of the $2 H$ or $4 H-$ pyran scaffold (Fig. 1). Thus, the benzo derivative of $2 H$-pyran is called $4 H$-1-benzopyran (commonly $4 H$-chromene)named and the benzo analogue of $4 H$-pyran is $2 H$-1-benzopyran (commonly $2 H$-chromene).[1] The parent molecules being pyran-2-one and pyran-4-one. Paltry names are utilized for the related benzo analogues; coumarin, dihydrocoumarin, chromone. The diverse anticancer capabilities of pyrans have been additionally evidenced by the fact that this heterocycle has recently been a focal point for researchers worldwide.[2]. 
<smiles>C1=CCOC=C1</smiles><smiles>C1=COC=CC1</smiles><smiles>O=c1cccco1</smiles>
2H-Pyran 4H-Pyran Pyran-2-one<smiles>C1=COc2ccccc2C1</smiles>

4H-1-Benzopyran<smiles>O=c1ccoc2ccccc12</smiles>

Chromone<smiles>O=c1ccocc1</smiles>
Pyran-4-one<smiles>O=c1ccc2ccccc2o1</smiles>

Coumarin<smiles>O=C1CCOc2ccccc21</smiles>

Chroman-4-one
Dihydrocoumarin

\section{Figure 1: Pyran-based heterocycles}

Multi-component reactions (MCRs) have been successfully employed to generate highly diverse combinatorial libraries for high-throughput medicinal chemistry. In addition, use of water for the organic reactions has been an important and fertile area of research in recent years. The usefulness of MCR is even greater when they provide access to "privileged medicinal scaffolds". One such significant scaffold is the pyran nucleus which is the key constituent of a wide range of both natural and synthetic bioactive compounds. The compounds containing $4 H$-chromene scaffold have found other applications such as optical brighteners, [3] fluorescence markers, [4] pigments, [5] cosmetics, biodegradable agrochemicals, [6] mutagenicity, [7] sex pheromone, [8] laser dyes, [9] central nervous system activity, [10] and $\mathrm{pH}$ sensitive fluorescent materials for visualization of biomolecules.[11] Moreover, 7-Hydroxy-6methoxy-4H-chromene A (Fig. 2) is an example of naturally occurring $4 H$-chromene, which was obtained from the flowers of Wisteria sinensis and is one of their fragrance components.[12] Among different types of chromene systems, 2-Amino-4H-chromenes have been reported to exhibit highly useful proapoptotic properties for the treatment of a wide range of cancer ailments.[13] In cancer chemotherapy, 2-Amino-4H-chromene $\mathrm{B}$ was marked for drug development due to its high inhibition of tumorassociated Bcl-2 proteins.[14] A modified 4H-chromene structure $\mathrm{C}$ was able to induce apoptosis (programmed cell death) in several cancer cell lines.[15]

In particular, 2-Amino-4H-chromene derivatives are of recent interest for their antitumor activities.[16] In addition, $4 H$-chromene derivatives observed some biological and pharmacological effects such as treatment of advanced solid tumors, [17] blood anticoagulant warfarin, [18] anticancer therapeutic, [19] inhibitor of Bcl-2 protein and apoptosis inducer.[20] Multi-component reactions (MCRs) have been successfully employed to generate highly diverse combinatorial libraries for high-throughput screening of biological and pharmacological activities.[21]

A variety of natural and synthetic derivatives of chromene have important biological and pharmacological applications, such as antimicrobial, [22] anti-inflammatory, [23] antiproliferative, [24] antioxidant, [25] herbicidal, analgesic and anticonvulsant, [26] antitubercular,[27] anticoagulant, estrogenic antispasmolytic, estrogenic, [28-37] TNF- $\alpha$ inhibitor effects and activities, [38] as well as inhibitor of diabetes-induced vascular dysfunction. $[39,40]$ Such diverse biological and pharmacological activities have made chromene derivatives important for further development in medicinal and organic synthesis studies.[41].<smiles>COc1cc2c(cc1O)OC(N)=C(C#N)C2</smiles>

Natural occurring 4h-chromene (A)<smiles>N#CC1=C(N)Oc2c(c(=O)oc3ccccc23)C1c1ccccc1</smiles>

Antirheumatic<smiles>[R]c1cccc(C2C(C#N)=C(N)Oc3c2c(C)nn3-c2ccc(F)cc2)c1</smiles><smiles>CCOCC(C#N)C1C(C(=O)OCC)=C(N)Oc2ccc(Br)cc21</smiles>

High inhibition of tumor-associated $\mathrm{Bcl}-2$ proteins (B)<smiles>[R]c1ccc(C2C(C#N)=C(N)Oc3c2c(=O)oc2ccccc32)cc1</smiles>

$\mathrm{R}=3-\mathrm{NO}_{2} / 3.4-(\mathrm{OH})_{2}$

Anticancer<smiles>[R]c1cccc(C2C(C#N)=C(N)Oc3[nH]nc(C)c32)c1</smiles>

CH1-Kinase inhibitor<smiles>COc1cc(C2C(C#N)=C(N)Oc3c2ccc2c3ccn2C)cc(Br)c1OC</smiles>

(C)<smiles>[R]c1cccc(C2C(C#N)=C(N)Oc3cc(N(C)C)ccc32)c1</smiles>

Anticancer<smiles>[R]c1cccc(C2C(C#N)=C(N)OC3=C2C(=O)CC(C)(C)C3)c1</smiles>

$X=0 /$ S: Anticancer $\mathrm{X}=\mathrm{NH}$ : Antibacterial

$=3-\mathrm{NO}_{2} / 3.4-(\mathrm{OH})_{2}$ Antibacterial

Figure 2: Structure of some biologically important 2-Amino-3-cyano-4H-chromenes 
The field of organic synthesis has recently experienced numerous innovative scientific breakthroughs accompanied by improved and efficient synthetic protocols that avoid the use of toxic reagents. Rather than being a discipline itself, Green chemistry encompasses a series of considerations in the design of environmentally benign protocols comprising subjects such as energy consumption, atom efficiency, and sustainability of chemical processes. A major point in the design of greener and more sustainable processes relates to the efficiency of the process, which has to take into account several parameters including energy, material consumption (preferably use of bio renewable resources), man-power (automation), and reactor usage (e.g. flow versus batch reactions). Concepts such as "atom-economy"[41] and efforts towards minimization of auxiliary chemicals (which include protection-deprotection sequences and use of volatile organic solvents) form the pillars of material efficiency in chemical production. In chemical reactions, solvents play a very important role in extractions, reactants solubility, washing, and separation of final products. For the past two decades, scientists have devoted a great deal of research effort to replace toxic and harmful solvents by more environmentally benign alternatives.[2] Water is among the most widely explored greener alternatives in recent years.

In general water is considered a "green solvent" for organic reactions; though, chemical reactions performed "in- or onwater" are not generally considered as greener reactions and often do not meet the requirements of ideal green processes. The aim of this work is to provide a comprehensive overview of the most promising, alternative greener methodologies that can be employed in organic synthesis with the purpose of designing safer, more benign as well as low environmental impact processes, which can lead to improved efficiencies for industrial applications. In my research catalyst free synthesise of 2-Amino-3-cyano$4 H$-benzopyran in aqueous medium based on multi- component reaction. Naturally occurring and man made benzopyrans derivatives have attracted great interest to researchers, because their excellent biological and pharmacological properties (Fig.2).

\section{Organic reactions in aqueous media}

Early 1980s, the use of water as solvent for organic reaction was limited, although in 1931 the very first known example was reported by Diels and Alder for the cycloaddition reaction in water. In the 1980s Breslow can revisited The use of water as a solvent in organic chemistry, the rate of several organic reactions could strongly enhance by hydrophobic effects. Notably, in the exploration of new "green" procedures, synthetic organic conversions was found to be useful in high temperature water (HTW). Water is the solvent of choice not only from an environmental standpoint but also from an economic point of view since it is cheap, non-flammable, and abundantly available. Compared with common organic solvents, the unique and unusual physical properties such as high specific heat, high surface tension, high dielectric constant, large cohesive energy density and chemical properties (ability to form hydrogen bonds and amphoteric nature) of water can in principle influence positively the reactivity and selectivity of chemical reactions (Fig. 3).

\section{The main advantages of using water are based on:}

$>$ Its flexibility to form strong hydrogen bonds that give it a significant surface tension (three times that of liquid ammonia) - which could facilitate the aggregation of reactants.

> Its ability to form weak non-covalent bonds with other compounds.

$>\quad$ Its ability to engage in electron transport reactions as exemplified by many biological and synthetic reactions.

\section{water as a solvent}

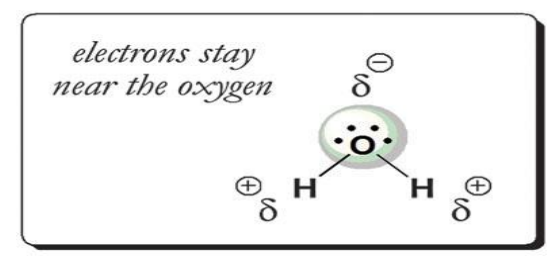

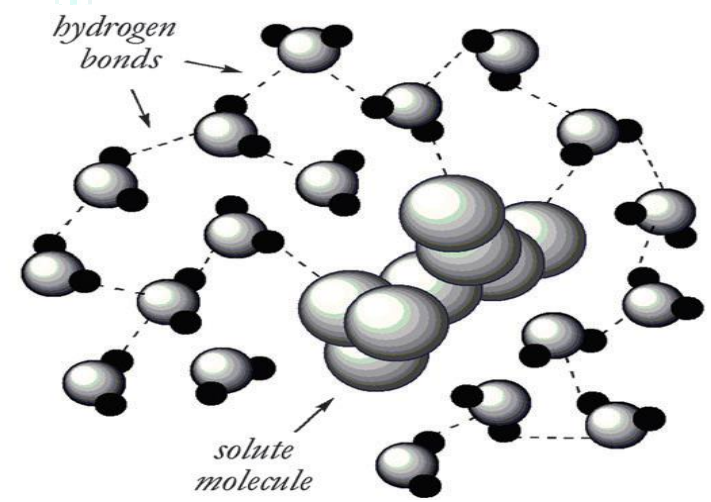

molecule

Figure 3: Chemical structure of water and its physical interactions with solute molecules Catalyst-free on-water organic reactions

Recently, this concept was revisited by Sharpless and coworkers with some representative reactions where water insoluble reactants are converted to products in high yields; the reaction mixture is usually stirred vigorously in water for a short period. The representative examples included cycloadditions, such as classic Diels-Alder reactions, as well as nucleophilic ring-opening of epoxides and aromatic Claisen rearrangements. Since the reactants were insoluble in water, the reactions were described as being on-water Due to the aforementioned versatile and unique properties of water, rates and selectivities of pericyclic reactions under on-water conditions can be improved, as well as in a series of related organic transformations in the presence and/or absence of catalysts.

\section{Catalyst-free reactions in-water}

For Catalyst-free organic reactions water can be used as a better medium. Currently, organic reactions that are carried out in water are classified as on-water or in-water, depending on the solubility of chemical components. According to Breslow, in-water, the organic molecules are forced to form aggregates in order to decrease the exposed organic surface area. Due to these aggregates, holes are formed in the cluster structure of liquid water and the bulk 
water molecules surround or hydrate the aggregates. In the final layer of the hydration shell, as the bulk water molecules approach the surface of small aggregates their H-bond links run laterally along the hydrophobic surface. This effect is known as the "Breslow hydrophobic effect". With large hydrophobic surfaces some dangling hydrogen bond $\mathrm{COH}-$ free) groups are orientated toward the barrier to maximize the packing density of the molecule. In the last few decades in-water reactions have been studied in detail, the main characteristics being: (a) hydrophobicity, which speeds up reactions; (b) hydrogen bonding, with impact on reactants and transition states which may or may not favor the hydrophobic effect; and (c) water polarity, which may again increase or decrease the reaction rates.

Traditionally, we have achieved nucleophilic addition reaction to used alkali metal hydroxides, pyridine, and piperidine as catalysts by the reaction of active methylene to a carbonyl group followed by dehydration [Knoevenagel condensation]. Frequently some organic reaction reported an uncatalyzed tandem Knoevenagel condensation and Michael addition reactions are performed in aqueous media. Organic synthesis can play a lead role in addition reactions, due to their importance in the preparation of key pharmaceutical intermediates and other compounds. Synthesis of benzopyrans and their derivatives are important moieties in various pharmaceutical and chemical syntheses and have broad scope in biological activities such as antipyretics and analgesics, their synthesis is normally conducted using acid catalysts and expensive reagents. Vasuki and Kumaravel investigated the uncatalyzed synthesis of a combinatorial library of 2-Amino-4-(5hydroxy-3-methyl-1-Hpyrazol- 4-yl)-4H-chromene-3carbonitrile derivatives via a four component reaction between hydrazine hydrate, ethyl acetoacetate, 2hydroxybenzaldehydes, and malononitrile in-water at room temperature this multicomponent catalyst-free protocol in aqueous media is highly atom economic with ethanol and water being the only byproduct of the reaction. Recent two decade plenty of methods have been followed by the syntheses $4 H$ - pyran and its derivatives.[41]

\section{RESULT AND DISCUSSION}

First we examined the multicomponent domino reaction of malononitrile, aryl aldehyde and resorcinol was chosen as the model reaction. The effect of various reaction parameters such as the influence of solvent, formation of hydrogen bond and the effect of temperature were studied to optimize the reaction conditions (Table 1). It is important to note that $\mathrm{K}_{2} \mathrm{CO}_{3}$ and $\mathrm{Na}_{2} \mathrm{CO}_{3}$ was found to be the catalyst for the three component reaction of malanonitrile, aryl aldehyde and resorcinol affording a considerable yield of the desired product. Moreover in the absence of catalyst a significant product formation was observed under reflux condition (Table 1, entry 14).

The solvent temperature plays an important role in the reactivity (Table 1). We have investigated the effect of various protic, aprotic and non-polar solvents on the three component reaction of resorcinol, aryl aldehyde and malononitrile (Table 1, entry 1-14). In non-polar solvents such as 1,4-dioxane and Toluene, the yield of the reaction was found to be very low $(10-20 \%)$ (Table 1, entry $5,6,11,12)$. Whereas in the case of polar aprotic solvents such as THF, acetonitrile, the yield of the reaction was found to be low (8-15\%) (Table 1, entry 3,4,9,10). In the case of polar protic solvents such as ethanol and methanol (Table 1, entry 1,2,7,8), the yield of the desired product was considerable (50-65\%). Further increase in the reaction temperature to reflux makes the reaction almost quantitative (Table 1, entry 14). From Table 1, it is clear that water was the best choice as solvent.

We examined the substrate scope of substituted benzaldehydes $(\mathbf{2 a}-\mathbf{2} \mathbf{n})$ under optimized reaction condition for the synthesis of chromene derivatives (4a-4n). All the electron donating and electron withdrawing aldehydes are compatible with optimized reaction condition afforded the excellent yield $80-93 \%$.

Table 1 Optimization of reaction conditions

\begin{tabular}{cccccc}
\hline Entry & Base & Solvent & Temp $\left({ }^{\circ} \mathrm{C}\right)$ & $\begin{array}{c}\text { Time } \\
(\mathrm{min})\end{array}$ & $\begin{array}{c}\text { Yield 4a } \\
(\%)\end{array}$ \\
\hline 1 & $\mathrm{Na}_{2} \mathrm{CO}_{3}$ & EtOH & 60 & 30 & 50 \\
2 & $"$ & $\mathrm{MeOH}$ & 50 & 30 & 55 \\
3 & $"$ & THF & 50 & 30 & 10 \\
4 & $"$ & Acetonitrile & 60 & 30 & 8 \\
5 & $"$ & Dioxane & 60 & 30 & 15 \\
6 & $"$ & Toluene & 80 & 30 & 10 \\
7 & $\mathrm{~K}_{2} \mathrm{CO}_{3}$ & EtOH & 60 & 30 & 60 \\
8 & $"$ & MeOH & 50 & 30 & 65 \\
9 & $"$ & THF & 50 & 30 & 15 \\
10 & $"$ & Acetonitrile & 60 & 30 & 10 \\
11 & $"$ & Dioxane & 60 & 30 & 20 \\
12 & $"$ & Toluene & 80 & 30 & 12 \\
13 & - & $\mathbf{H}_{2} \mathbf{O}$ & $\mathbf{6 0}$ & $\mathbf{3 0}$ & $\mathbf{5 0}$ \\
14 & - & $\mathbf{H}_{2} \mathbf{O}$ & reflux & $\mathbf{1 5 - 2 0}$ & $\mathbf{8 0 - 9 3}$ \\
\hline
\end{tabular}

\section{Chemistry}

2-Amino-3cyano-4H-benzopyrans (4a-n) was prepared via multi-component reaction, malononitrile (1) with substituted aromatic aldehydes (2) resorcinol (3) and in aqueous medium conditions for $15-20 \mathrm{~min}$ at $120^{\circ} \mathrm{C}$ as shown in (Scheme1). The assignment structures $\mathbf{4 h}$ and $\mathbf{4 i}$ were confirmed on the basis of spectral data and single crystal XRD method. The IR spectra of $\mathbf{4 a - 4 n}$ showed the appearance of the $-\mathrm{OH}$ stretch at $3476-3435 \mathrm{~cm}^{-1},-\mathrm{NH}_{2}$ stretch at 3348-3330, 3265-3210 $\mathrm{cm}^{-1}$ and -CN stretch at 2199-2180 $\mathrm{cm}^{-1}$. The ${ }^{1} \mathrm{H}$ and ${ }^{13} \mathrm{C}$ NMR spectra of $\mathbf{4 a}-4 \mathbf{n}$ revealed the presence of $4 \mathrm{H}$ signals at $\delta 5.66-4.40(\mathrm{~s}, 1 \mathrm{H}, \mathrm{H}-$ 4), 56.05-35.00 ppm (C-4) and $\mathrm{OH}$ signals at $\delta$ 9.99-9.40 ppm. In addition, the mass spectra of compounds $\mathbf{4 h}$ and $\mathbf{4 i}$ and X-ray diffraction gave also additional evidences for established the proposed structures. 
Structure of synthesised compounds $(4 a-4 n)$

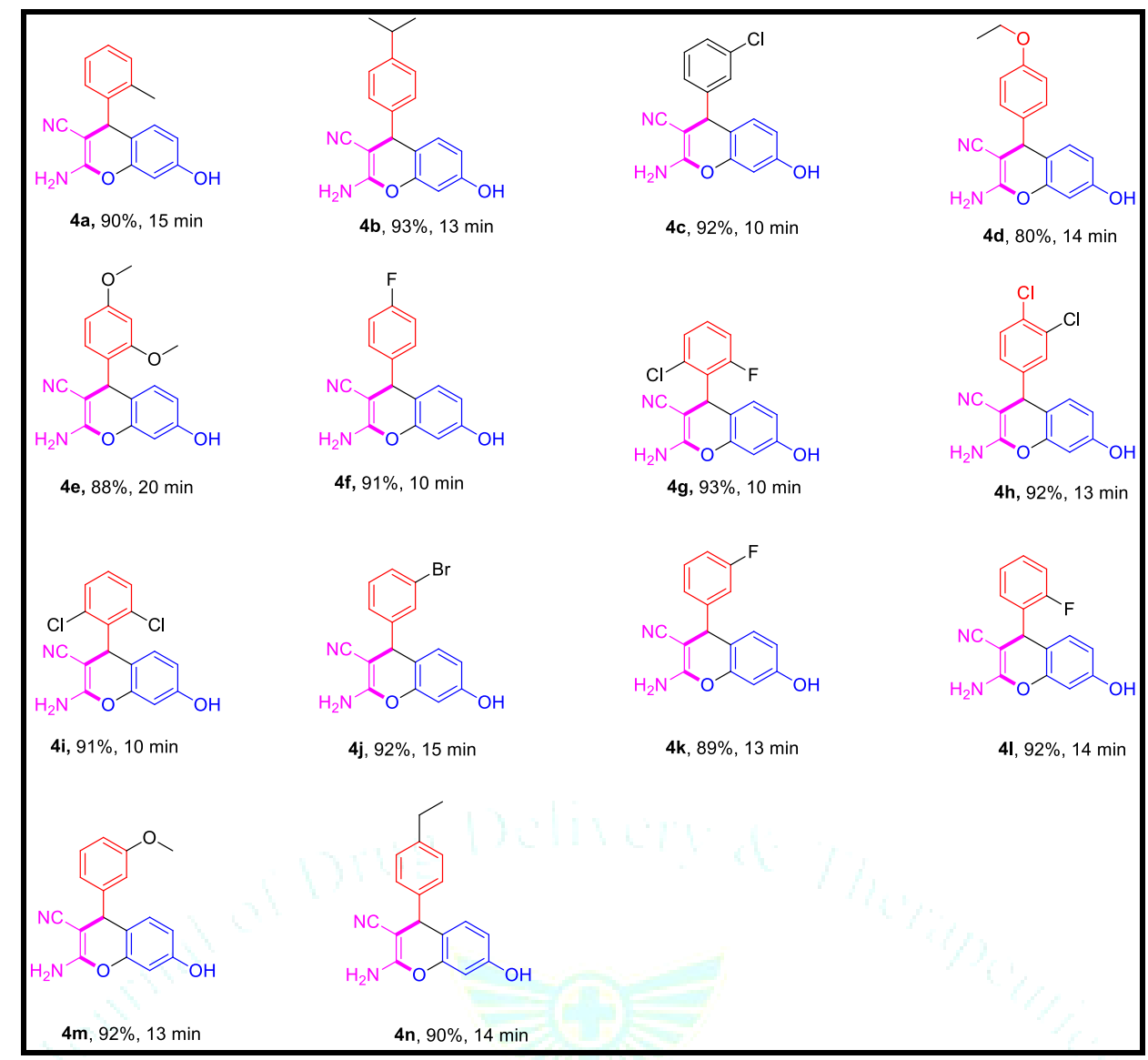

Table 2: Synthesis of 2-Amino-3cyano-4H-benzopyran in aqueous medium

\begin{tabular}{|l|l|l|l|l|l|l|}
\hline Entry & \multicolumn{1}{|c|}{$\mathrm{R}$} & $\begin{array}{l}\text { Molecular } \\
\text { formula }\end{array}$ & $\begin{array}{l}\text { Molecular } \\
\text { Weight }\end{array}$ & $\begin{array}{l}\text { Time } \\
\text { (minute) }\end{array}$ & Yield (\%) & m.p ${ }^{\circ} \mathrm{C}$ \\
\hline $4 \mathrm{a}$ & $2-\mathrm{CH}_{3}$ & $\mathrm{C}_{17} \mathrm{H}_{14} \mathrm{~N}_{2} \mathrm{O}_{2}$ & 278 & 20 & 98 & 210 \\
\hline $4 \mathrm{~b}$ & $4-\mathrm{CH}\left(\mathrm{CH}_{3}\right)_{2}$ & $\mathrm{C}_{19} \mathrm{H}_{18} \mathrm{~N}_{2} \mathrm{O}_{2}$ & 306 & 15 & 99 & 225 \\
\hline $4 \mathrm{c}$ & $3-\mathrm{Cl}$ & $\mathrm{C}_{16} \mathrm{H}_{11} \mathrm{ClN}_{2} \mathrm{O}_{2}$ & 298 & 10 & 99 & 245 \\
\hline $4 \mathrm{~d}$ & $4-\mathrm{OC}_{2} \mathrm{H}_{5}$ & $\mathrm{C}_{18} \mathrm{H}_{16} \mathrm{~N}_{2} \mathrm{O}_{3}$ & 308 & 15 & 95 & 230 \\
\hline $4 \mathrm{e}$ & $2,4-\mathrm{CCH}_{3}$ & $\mathrm{C}_{18} \mathrm{H}_{16} \mathrm{~N}_{2} \mathrm{O}_{4}$ & 324 & 10 & 92 & 210 \\
\hline $4 \mathrm{f}$ & $4-\mathrm{F}$ & $\mathrm{C}_{16} \mathrm{H}_{11} \mathrm{FN}_{2} \mathrm{O}_{2}$ & 282 & 10 & 96 & 250 \\
\hline $4 \mathrm{~g}$ & $2-\mathrm{Cl}, 4-\mathrm{F}$ & $\mathrm{C}_{16} \mathrm{H}_{10} \mathrm{ClFN}_{2} \mathrm{O}_{2}$ & 316 & 20 & 90 & 210 \\
\hline $4 \mathrm{~h}$ & $3,4-\mathrm{Cl}$ & $\mathrm{C}_{16} \mathrm{H}_{10} \mathrm{C}_{12} \mathrm{~N}_{2} \mathrm{O}_{2}$ & 332 & 10 & 99 & 244 \\
\hline $4 \mathrm{i}$ & $2,6-\mathrm{Cl}$ & $\mathrm{C}_{16} \mathrm{H}_{10} \mathrm{Cl}_{2} \mathrm{~N}_{2} \mathrm{O}_{2}$ & 332 & 10 & 99 & 262 \\
\hline $4 \mathrm{j}$ & $3-\mathrm{Br}$ & $\mathrm{C}_{16} \mathrm{H}_{11} \mathrm{BrN}_{2} \mathrm{O}_{2}$ & 342 & 15 & 97 & 215 \\
\hline $4 \mathrm{k}$ & $3-\mathrm{F}$ & $\mathrm{C}_{16} \mathrm{H}_{11} \mathrm{FN}_{2} \mathrm{O}_{2}$ & 282 & 16 & 96 & 218 \\
\hline $4 \mathrm{l}$ & $2-\mathrm{F}$ & $\mathrm{C}_{16} \mathrm{H}_{11} \mathrm{FN}_{2} \mathrm{O}_{2}$ & 282 & 10 & 94 & 222 \\
\hline $4 \mathrm{~m}$ & $3-\mathrm{OCH}$ & $\mathrm{C}_{17} \mathrm{H}_{14} \mathrm{~N}_{2} \mathrm{O}_{3}$ & 294 & 17 & 95 & 263 \\
\hline $4 \mathrm{n}$ & $4-\mathrm{C}_{2} \mathrm{H}_{5}$ & $\mathrm{C}_{18} \mathrm{H}_{16} \mathrm{~N}_{2} \mathrm{O}_{2}$ & 292 & 20 & 88 & 248 \\
\hline
\end{tabular}

The structure of $\mathbf{4 h}$ and $\mathbf{4 i}$ were confirmed by X-ray diffraction analysis, as shown in figures 4 and 5 respectively. The selected crystallographic data are listed in Table 3. The orientation of the benzopyran and chlorophenyl rings are confirmed from the torsion angle value $\left[\mathrm{C}_{5}-\mathrm{C}_{6}-\mathrm{C}_{7}-\mathrm{C}_{8}=\right.$ 133.6(3응, $\left.\mathrm{C}_{1}-\mathrm{C}_{6}-\mathrm{C}_{7}-\mathrm{C}_{8}=47.4\left(4^{\circ}\right)\right]$. In the benzopyran moiety, attached carbonitrile, amino and hydroxy groups lie in same plane. Empirical formula $\mathrm{C}_{22} \mathrm{H}_{15} \mathrm{Cl}_{2} \mathrm{~N}_{2} \mathrm{O}_{2}, \quad M r=410.26$, Monoclinic, Space group P2(1)/c, a=12.753(9) $\AA$, $b=6.665(4) \AA, c=24.050(14) \AA, \beta=102.95(3) A^{\circ}, V=1992(2)$
$\AA^{3}, \mathrm{Z}=4$, Dcalc $=1.368 \mathrm{mg} / \mathrm{m}^{3}, \mathrm{~F}(000)=844, \mu=0.346 \mathrm{~mm}^{-1}$, crystal dimension $0.150 \times 0.150 \times 0.100 \mathrm{~mm}^{3}$. Intensity data were collected at $294(\mathrm{~K}), \lambda=0.71073 \mathrm{~nm}$. A total of 34682 reflection were collected with 3492 unique (Rint=0.0334). The final $\mathrm{R}$ and $W \mathrm{R}$ values are 0.0671 and 0.2114 e. $\AA^{-3}$, $\mathrm{S}=1.080$. The maximum peak and minimum peak in the final difference map are 0.718 and -0.637 e. $\AA^{-3}$. The sum of the bond angles around the atom $\mathrm{N} 1$ of the pyran ring is in accordance with $\mathrm{sp}^{2}$ hybridization state. 


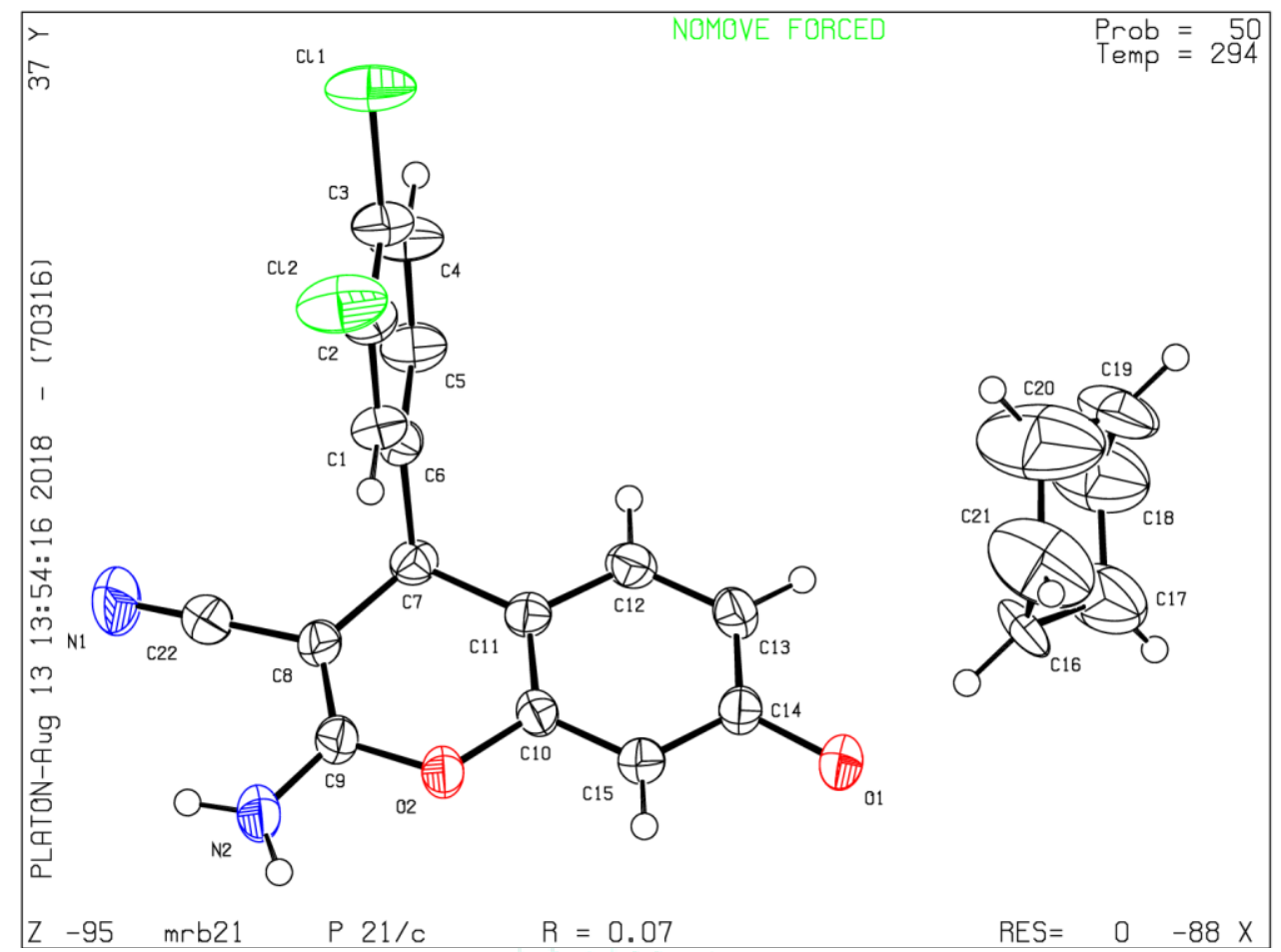

Figure 4: ORTEP diagram of compound 4h

The orientation of the benzopyran and chlorophenyl ring in molecule $4 \mathrm{i}$ is confirmed from the torsion angle value $\left[\mathrm{C}_{8}-\mathrm{C}_{7-}\right.$ $\left.\mathrm{C}_{6}-\mathrm{C}_{5}=-54.0\left(2^{\circ}\right), \quad \mathrm{C}_{8}-\mathrm{C}_{7}-\mathrm{C}_{6}-\mathrm{C}_{1}=128.47\left(17^{\circ}\right)\right]$. In the benzopyran moiety, attached amino carbonitrile and hydroxy groups lie in same plane. Empirical formula $\mathrm{C}_{16} \mathrm{H}_{10} \mathrm{Cl}_{2} \mathrm{~N}_{2} \mathrm{O}_{2}, \quad M r=333.16$, Triclinic, Space group $\mathrm{P}-1$, $\mathrm{a}=6.271(3) \AA \mathrm{A}, \mathrm{b}=18.697(5) \AA$, $\mathrm{c}=13.794(7) \AA$, $\beta=94.269(17) A^{\circ}, V=712(7) \AA^{3}, Z=2$, Dcalc $=1.553 \mathrm{mg} / \mathrm{m}^{3}$, $\mathrm{F}(000)=340, \mu=0.643 \mathrm{~mm}^{-1}$, crystal dimension $0.150 \times 0.150$ x $0.100 \mathrm{~mm}^{3}$. Intensity data were collected at $294 \mathrm{~K}$ $\lambda=0.71073 \mathrm{~nm}$. A total of 22289 reflection were collected with 2499 unique (Rint $=0.0226$ ). The final $\mathrm{R}$ and $W \mathrm{R}$ values are 0.0336 and $0.0868, S=1.130$.The maximum peak and minimum peak in the final difference map are 0.226 and 0.272 e. $\AA^{-3}$. The sum of the bond angles around atom N1 of the pyran ring is in accordance with $\mathrm{sp}^{2}$ hybridization state[360].

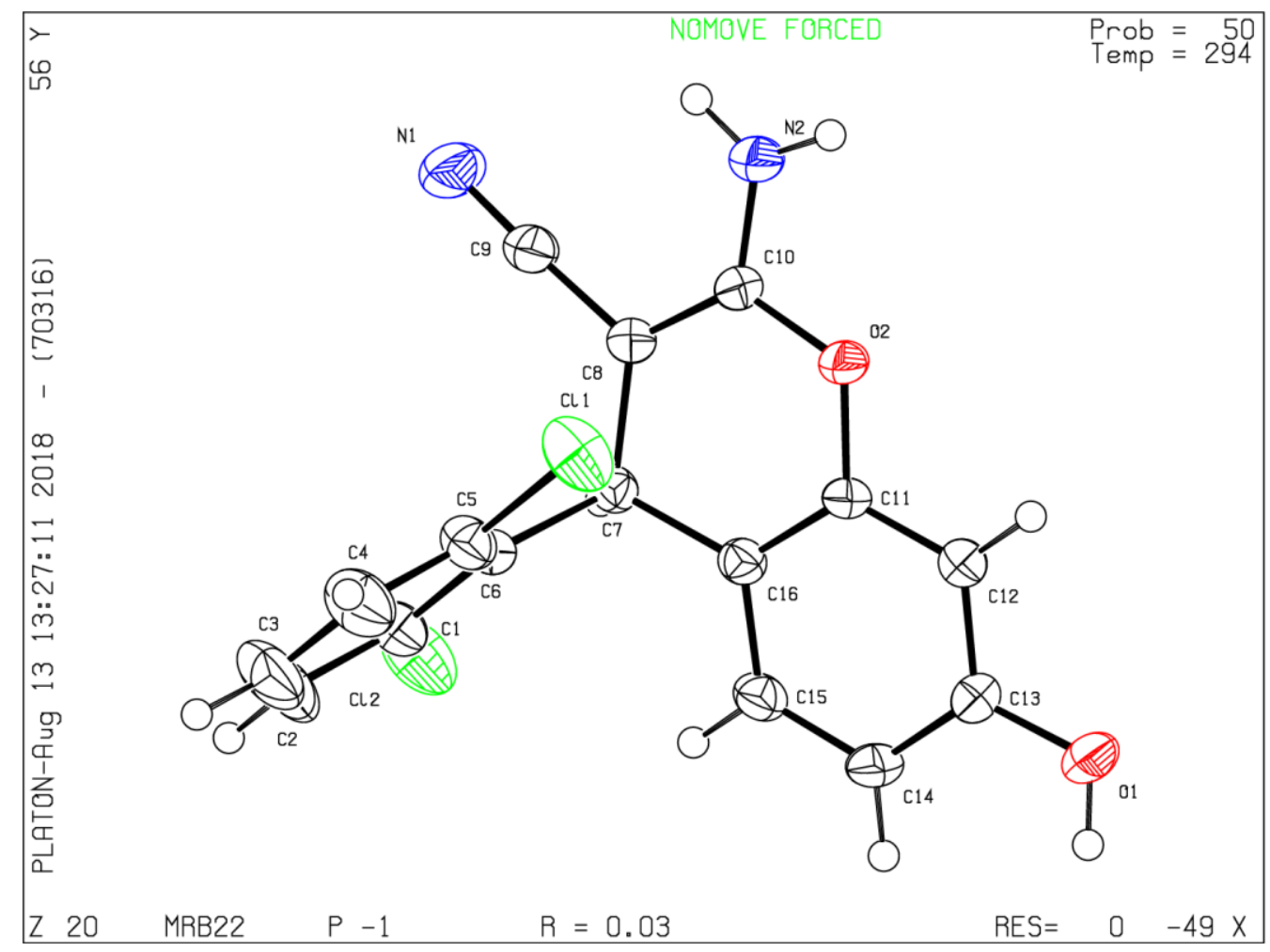

Figure 5: ORTEP diagram of compound 4i 
A sequentional reaction of Knoevenagal condensation and Michael-addition followed the intramolecular cyclization may take place during the formation of the product. The possible mechanism is shown in scheme 1.

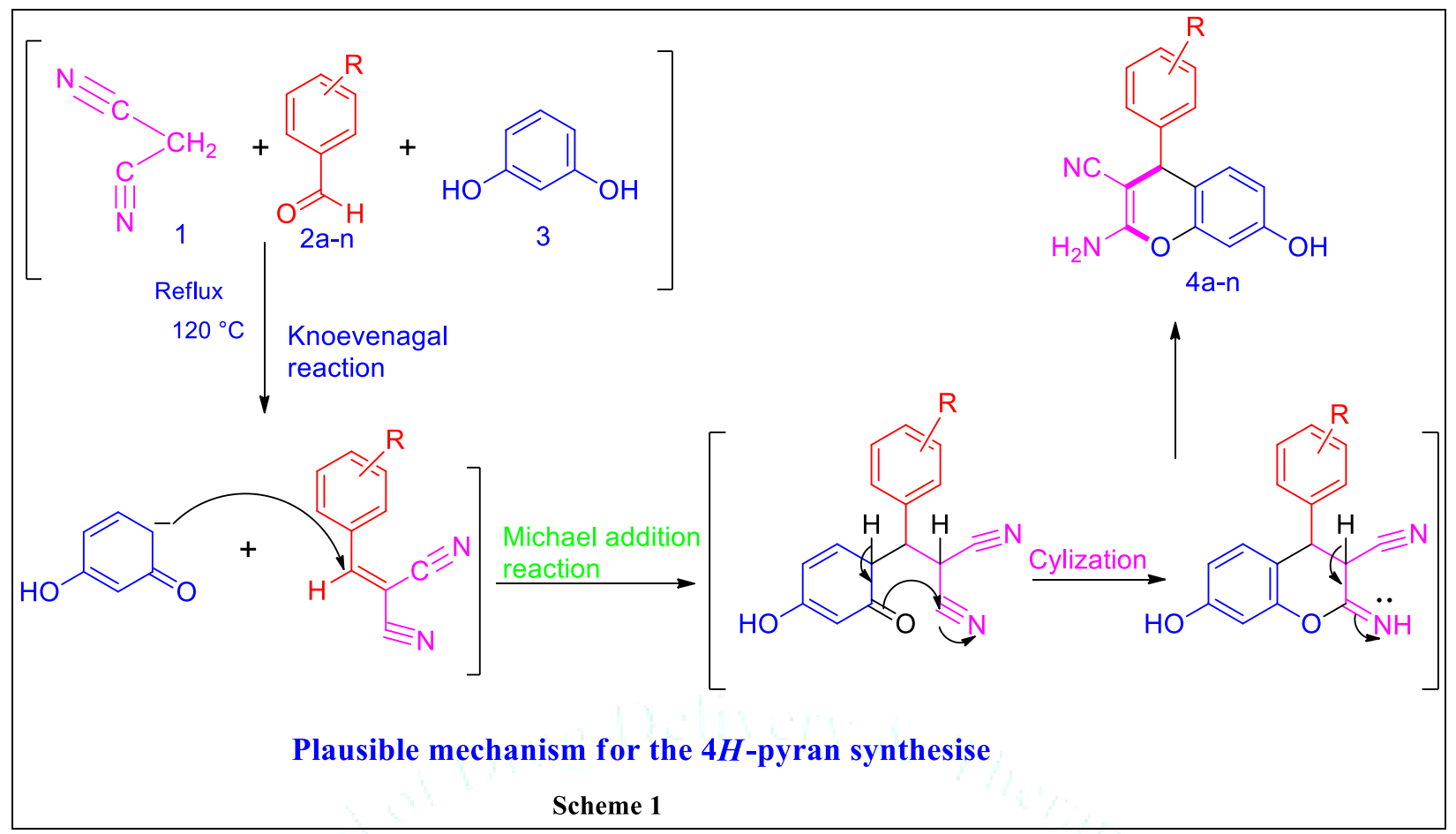

Table 3: Crystallographic data for $4 \mathrm{~h}$ and $4 \mathrm{i}$

\begin{tabular}{|c|c|c|}
\hline Compound & $4 \mathrm{~h}$ & $4 i$ \\
\hline Identification code & mrb21 & mrb22 \\
\hline Empirical formula & $\mathrm{C}_{22} \mathrm{H}_{15} \mathrm{Cl}_{2} \mathrm{~N}_{2} \mathrm{O}_{2}$ & $\mathrm{C}_{16} \mathrm{H}_{10} \mathrm{Cl}_{2} \mathrm{~N}_{2} \mathrm{O}_{2}$ \\
\hline Formula weight & 410.26 & 333.16 \\
\hline Temperature & $294(2) \mathrm{K}$ & $294(2) \mathrm{K}$ \\
\hline Wavelength & $0.71073 \AA$ & $0.71073 \AA$ \\
\hline Crystal system & Monoclinic & Triclinic \\
\hline Space group & $\mathrm{P} 21 / \mathrm{c}$ & $\mathrm{P}-1$ \\
\hline Unit cell dimensions & $\begin{array}{l}a=12.753(9) \AA, a=90^{\circ} . \\
b=6.665(4) \AA, b=102.95(3)^{\circ} \\
c=24.050(14) \AA, g=90^{\circ} .\end{array}$ & $\begin{array}{l}\mathrm{a}=6.271(3) \AA, \mathrm{a}=107.06(2)^{\circ} . \\
\mathrm{b}=8.697(5) \AA, \mathrm{b}=94.269(17)^{\circ} . \\
\mathrm{c}=13.794(7) \AA, \mathrm{g}=95.00(3)^{\circ} .\end{array}$ \\
\hline Volume & $1992(2) \AA^{3}$ & $712.5(7) \AA^{3}$ \\
\hline Z & 4 & 2 \\
\hline $\begin{array}{l}\text { Density (calculated) } \\
\text { Absorption coefficient }\end{array}$ & $1.368 \mathrm{Mg} / \mathrm{m}^{3}$ & $1.553 \mathrm{Mg} / \mathrm{m}^{3}$ \\
\hline $\mathrm{F}(000)$ & $0.346 \mathrm{~mm}^{-1}$ & $0.463 \mathrm{~mm}^{-1}$ \\
\hline Crystal size & 844 & 340 \\
\hline Theta range for data collection & $0.150 \times 0.150 \times 0.100 \mathrm{~mm}^{3}$ & $0.150 \times 0.150 \times 0.100 \mathrm{~mm}^{3}$ \\
\hline Index ranges & 3.178 to $24.998^{\circ}$. & 3.872 to $25.000^{\circ}$ \\
\hline Reflections collected & $-15<=\mathrm{h}<=15,-7<=\mathrm{k}<=7,-28<=\mathrm{l}<=26$ & $-7<=\mathrm{h}<=7,-10<=\mathrm{k}<=10,-16<=\mathrm{l}<=16$ \\
\hline Independent reflections & 34682 & 22289 \\
\hline Completeness to theta $=$ & $3492[\mathrm{R}(\mathrm{int})=0.0334]$ & $2499[\mathrm{R}$ (int) $=0.0226]$ \\
\hline Absorption correction & $24.998^{\circ}, 99.7 \%$ & $25.000^{\circ}, 98.9 \%$ \\
\hline Max. and min. transmission & Semi-empirical from equivalents & Semi-empirical from equivalents \\
\hline Refinement method & 0.7454 and 0.7035 & 0.7461 and 0.7041 \\
\hline Data / restraints / parameters & Full-matrix least-squares on $\mathrm{F}^{2}$ & Full-matrix least-squares on $\mathrm{F}^{2}$ \\
\hline Goodness-of-fit on $\mathrm{F}^{2}$ & $3492 / 0 / 253$ & 2499 / 0 / 211 \\
\hline Final R indices [I>2sigma(I)] & 1.080 & 1.130 \\
\hline $\mathrm{R}$ indices (all data) & $\mathrm{R} 1=0.0671, \mathrm{wR} 2=0.1949$ & $\mathrm{R} 1=0.0336, \mathrm{wR} 2=0.0795$ \\
\hline \multirow[t]{2}{*}{ Largest diff. peak and hole } & $\mathrm{R} 1=0.0803, \mathrm{wR} 2=0.2114$ & $\mathrm{R} 1=0.0392, \mathrm{wR} 2=0.0868$ \\
\hline & 0.718 and -0.637 e. $\AA^{-3}$ & 0.226 and -0.272 e. $\AA^{-3}$ \\
\hline
\end{tabular}




\section{Experimental}

All the chemicals used were purchased from Merck AnalaR grade and purified wherever necessary using the standard purification method. The purity of compounds were checked by TLC using silica gel-G plate and visualized by iodine vapours The melting points were recorded in open capillary tube and uncorrected. The FT-IR spectra were recorded in SHIMADZU FT-IR Affinity-I spectrometer using $\mathrm{KBr}$ pellets and perkinealmer. The ${ }^{1} \mathrm{H}-\mathrm{NMR}$ and ${ }^{13} \mathrm{C}$-NMR spectra were obtained in DMSO- $\mathrm{d}_{6}$ on BRUKER $300 \mathrm{MHZ}$ and $500 \mathrm{MHZ}$ instrument with TMS as an internal standard and the chemical shift values are presented in ppm. The mass spectra were taken on SHIMADZU GC-MS QP 2010 spectrometer operating at an ionization potential of $70 \mathrm{ev}$.

\section{Synthesis of 2-Amino-7-hydroxy-4-(substituted} benzaldehyde)-4H-chromene-3-carbonitrile ( 4a-n)

To a stirred solution of benzoldehyde in a water was added resorcinol and malononitrile at room temperature and reflexed for 15 - 20 minutes. The progress of the reaction was monitored by thin layer chromatography using silica gel-G plates. The reaction mixture was cooled. The precipitated solid was filtered at suction pump. The crude solid obtained was recrystalized by methanol.

\section{2-Amino-7-hydroxy-4-(o-tolyl)-4H-chromene-3- carbonitrile $4 \mathrm{a}$}

IR: ( $\left.\mathrm{KBr} \mathrm{cm}^{-1}\right) 3421(\mathrm{OH}), 3337,3220\left(\mathrm{NH}_{2}\right), 3070(\mathrm{CH}-\mathrm{Ar})$, 2922 (CH-Aliphatic), 2193 (CN), 1653 (C=C) 1461 (C=C), 1110 (C-O-C), 1301 (C-N), 1 H NMR (300 MHz DMSO - $\mathrm{d}_{6}$ ): $\delta_{\mathrm{H}}$ $2.33\left(\mathrm{~S}, 3 \mathrm{H}, \mathrm{CH}_{3}\right), 4.93$ (S, $\left.1 \mathrm{H} \mathrm{m} \mathrm{H}-4\right), 6.47$ (d, $1 \mathrm{H}, J=2.1 \mathrm{~Hz}$, Ar-H) 6.48-6.52 (dd, 1H, J=2.4, $6 \mathrm{~Hz}, \mathrm{Ar}-\mathrm{H}), 6.65(\mathrm{~d}, 1 \mathrm{H}, J=$ 8.4, Ar-H), $6.84\left(\mathrm{~S}, 2 \mathrm{H}, \mathrm{NH}_{2}\right), 6.99(\mathrm{~d}, 1 \mathrm{H}, J=7.2 \mathrm{~Hz}, \mathrm{Ar}-\mathrm{H})$, 7.06-7.14 (m, 3H, Ar-H), 9.75 (s, H, OH). ${ }^{13} \mathrm{C}$ NMR (500 MHz DMSO d 6 ), $\delta_{c} 19.01,56.08,102.06,112.42,113.46,120.62$, $126.62,126.36,126.50,129.21,129.68,130.67,134.84$, $143.99,149.07,157.05,159.93$.

\section{2-Amino-7-hydroxy-4-(4-isopropylphenyl)-4H-} chromene-3-carbonitrile $4 \mathrm{~b}$

IR: (KBr cm$\left.{ }^{-1}\right) 3485(\mathrm{OH}), 3344,3264\left(\mathrm{NH}_{2}\right), 3070(\mathrm{CH}-\mathrm{Ar})$, 2961 (CH-Aliphatic), 2194 (CN), 1644 (C=C) 1462(C=C), 1343 (C-N),1154 (C-C), 1110 (C-O-C). $\mathrm{H}^{1}$ NMR (500 MHz DMSO - $\left.\mathrm{d}_{6}\right): \delta_{\mathrm{H}} 1.15\left(\mathrm{~d}, 6 \mathrm{H}, J=9 \mathrm{~Hz}, \mathrm{CH}_{3}\right), 2.79-2.84(\mathrm{~m}, 1 \mathrm{H}, \mathrm{Ali}-$ H), 4.56 (s, 1H, H-4), 6.79 (d, 1H, J=8.5 Hz, Ar-H), $6.84(\mathrm{~s}, 2 \mathrm{H}$, $\mathrm{NH}_{2}$ ), 7.05 (d, 2H, J=8 Hz, Ar-H), $9.71(\mathrm{~s}, 1 \mathrm{H}, \mathrm{OH}) \cdot{ }^{13} \mathrm{C}$ NMR (500 MHz DMSO d6), $\delta_{\mathrm{c}} 24.33,33.48,56.80,102.61,112.82$, $114.40,121.26,126.95,127.66,130.37,144.32,147.07$, $149.30,157.48,160.71$.

\section{2-Amino-4-(3-chlorophenyl)-7-hydroxy-4H-chromene- 3-carbonitrile 4c}

IR: (KBr cm-1) $3477(\mathrm{OH}), 3344,3244\left(\mathrm{NH}_{2}\right), 2924(\mathrm{CH}-\mathrm{Ar})$, 2890 (CH-Aliphatic), 2194 (CN), 1637 (C=C) 1457(C=C), 1346 (C-N),1151 (C-C), 1101 (C-O-C). H ${ }^{1}$ NMR (300 MHz DMSO - $\left.\mathrm{d}_{6}\right): \delta_{\mathrm{H}} 4.69(\mathrm{~s}, 1 \mathrm{H}, \mathrm{H}-4), 6.41(\mathrm{~d}, 1 \mathrm{H}, \mathrm{J}=2.4 \mathrm{~Hz}, \mathrm{Ar}-\mathrm{H})$, 6.48-6.52 (dd, $1 \mathrm{H}, J=2.4,6.0 \mathrm{~Hz}, \mathrm{Ar}-\mathrm{H}), 6.81(\mathrm{~d}, 1 \mathrm{H}, J=8.7 \mathrm{~Hz}$, Ar-H), 6.97 (s, 2H, NH 2 ), 7.13(d, 1H, J=6 Hz,Ar-H), 7.20-7.21 $(\mathrm{t}, 1 \mathrm{H}, \mathrm{J}=1.8 \mathrm{~Hz}, \mathrm{Ar}-\mathrm{H}), 7.26-7.32(\mathrm{~m}, 2 \mathrm{H}, \mathrm{Ar}-\mathrm{H}), 9.76(\mathrm{~s}, 1 \mathrm{H}$, OH). ${ }^{13} \mathrm{C}$ NMR (500 MHz DMSO d6), $\delta_{c} 24.33,33.48,56.80$, $102.61,112.82,114.40,121.26,126.95,127.66,130.37$, $144.32,147.07,149.30,157.48,160.71$.

\section{2-Amino-4-(4-ethoxyphenyl)-7-hydroxy-4H-chromene-} 3-carbonitrile 4d

IR: (KBr cm$\left.{ }^{-1}\right) 3428(\mathrm{OH}), 3333,3220\left(\mathrm{NH}_{2}\right), 3073(\mathrm{CH}-\mathrm{Ar})$, 2989 (CH-Aliphatic), 2193 (CN), 1659 (C=C) 1466 (C=C), 1339 (C-N), 1156 (C-C), 1111 (C-O-C). H NMR (500 MHz
DMSO - d6): $\delta \mathrm{H} 1.26\left(\mathrm{t}, 3 \mathrm{H}, J=7 \mathrm{~Hz}, \mathrm{CH}_{3}\right), 3.92-3.97(\mathrm{q}, 2 \mathrm{H}, J=7.7$ $\mathrm{Hz}, \mathrm{CH}_{2}$ ), 4.55 (s, 1H, H-4), 6.42 (d, 1H, J=2, Ar-H), 6.48-6.50 (dd, 1H, J= 2.5, $6 \mathrm{~Hz}, \mathrm{Ar}-\mathrm{H}), 6.77$ (d, 1H, J=8.5, Ar-H), 6.82 (d, $1 \mathrm{H}, J=1.0 \mathrm{~Hz}, \mathrm{Ar}-\mathrm{H}), 6.84\left(\mathrm{~s}, 2 \mathrm{H}, \mathrm{NH}_{2}\right), 7.05(\mathrm{~d}, 2 \mathrm{H}, J=9.0 \mathrm{~Hz}$ Ar-H), 9.72 (s, 1H, OH), ${ }^{13} \mathrm{C}$ NMR (500 MHz DMSO d6), $\delta_{\mathrm{c}} 15.05, \quad 57.09, \quad 63.39,102.60,112.81,114.56,114.82$, $121.24,128.88,130.39,130.62,138.81,149.24,157.43$, 160.58 .

\section{2-Amino-4-(2,4-dimethoxyphenyl)-7-hydroxy-4H- chromene-3-carbonitrile $4 \mathrm{e}$}

IR: (KBr cm$\left.{ }^{-1}\right) 3418(\mathrm{OH}), 3329,3218\left(\mathrm{NH}_{2}\right), 3029$ (CH-Ar), 2942 (CH-Aliphatic), 2197 (CN), 1644 (C=C) 1456 (C=C), 1377 (C-N), 1154 (C-C), 1112 (C-O-C). H1 NMR (500 MHz DMSO -d 6$): \delta_{\mathrm{H}} 3.71\left(\mathrm{~s}, 3 \mathrm{H}, \mathrm{OCH}_{3}\right), 3.76\left(\mathrm{~s}, 3 \mathrm{H}, \mathrm{OCH}_{3}\right), 4.87(\mathrm{~s}$, $1 \mathrm{H}, \mathrm{H}-4), 6.36$ (d, 1H, J=2.5, Ar-H), 6.43-6.46 (m, 2H, Ar-H), $6.53(\mathrm{~d}, 1 \mathrm{H}, J=2, \mathrm{Ar}-\mathrm{H}), 6.74\left(\mathrm{~s}, 2 \mathrm{H}, \mathrm{NH}_{2}\right) 6.79(\mathrm{~d}, 1 \mathrm{H}, J=8.5 \mathrm{~Hz}$, Ar-H), $9.63(\mathrm{~s}, 1 \mathrm{H}, \mathrm{OH}),{ }^{13} \mathrm{C}$ NMR $(500 \mathrm{MHz}$ DMSO $\left.\mathrm{d}_{6}\right), \delta_{\mathrm{c}} 55.10,55.90,56.19,102.47,105.65,105.93,112.59$, $114.78,115.75,121.32,126.94,129.68,131.18,157.20$, $159.69,161.43,162.74,166.02$.

\section{2-Amino-4-(4-fluorophenyl)-7-hydroxy-4H-chromene-3- carbonitrile $4 \mathrm{f}$}

IR: (KBr cm-1) $3429(\mathrm{OH}), 3340,3279\left(\mathrm{NH}_{2}\right), 3043$ (CH-Ar), 2882 (CH-Aliphatic), 2184 (CN), 1643 (C=C) 1457 (C=C), 1331 (C-N), 1152 (C-C), 1110 (C-O-C). H1 NMR (500 MHz DMSO - $\left.\mathrm{d}_{6}\right): \delta_{\mathrm{H}} 4.66(\mathrm{~s}, 1 \mathrm{H}, \mathrm{H}-4), 6.4(\mathrm{~d}, 1 \mathrm{H}, J=2.5, \mathrm{Ar}-\mathrm{H}), 6.48-$ $6.50(\mathrm{dd}, 1 \mathrm{H}, J=2.5,6 \mathrm{~Hz}, \mathrm{Ar}-\mathrm{H}), 6.77(\mathrm{~d}, 1 \mathrm{H}, J=8.5 \mathrm{~Hz}, \mathrm{Ar}-\mathrm{H})$, $6.88\left(\mathrm{~s}, 2 \mathrm{H}, \mathrm{NH}_{2}\right)$ 7.10-7.14 (t, $\left.2 \mathrm{H}, J=9 \mathrm{~Hz}, \mathrm{Ar}-\mathrm{H}\right), 7.18-7.21(\mathrm{q}$, $2 \mathrm{H}, J=5.5,3 \mathrm{~Hz}, \mathrm{Ar}-\mathrm{H}), 9.70(\mathrm{~s}, 1 \mathrm{H}, \mathrm{OH}),{ }^{13} \mathrm{C}$ NMR $(500 \mathrm{MHz}$ DMSO d 6 ), $\delta_{c} 56.66,102.67,112.91,114.01,115.67,115.67$, $115.84,121.02,129.67,129.67,129.74,130.36,149.28$, $157.61,160.46,160.46,160.66,162.39$.

\section{2-Amino-4-(2-chloro-6-fluorophenyl)-7-hydroxy-4H- chromene-3-carbonitrile $4 \mathrm{~g}$}

IR: (KBr cm-1$) 3421(\mathrm{OH}), 3327,3220\left(\mathrm{NH}_{2}\right), 3081$ (CH-Ar), 2937 (CH-Aliphatic), 2196 (CN), 1653 (C=C) 1454 (C=C), 1350 (C-N), 1149 (C-C), 1111 (C-O-C). H ${ }^{1}$ NMR (500 MHz DMSO - $\left.\mathrm{d}_{6}\right): \delta_{\mathrm{H}} 5.34(\mathrm{~s}, 1 \mathrm{H}, \mathrm{H}-4), 6.40(\mathrm{~d}, 1 \mathrm{H}, J=2.5 \mathrm{~Hz}, \mathrm{Ar}-\mathrm{H})$, 6.47-6.49 (dd, $1 \mathrm{H}, J=2,6.5 \mathrm{~Hz}, \mathrm{Ar}-\mathrm{H}), 6.68(\mathrm{~d}, 1 \mathrm{H}, J=3.5 \mathrm{~Hz}$, Ar-H) $6.93\left(\mathrm{~s}, 2 \mathrm{H}, \mathrm{NH}_{2}\right), 7.15(\mathrm{~s}, 1 \mathrm{H}, \mathrm{Ar}-\mathrm{H}), 7.31-7.34(\mathrm{t}, 2 \mathrm{H}$, $J=6.5 \mathrm{~Hz}, \mathrm{Ar}-\mathrm{H}), 9.74(\mathrm{~s}, 1 \mathrm{H}, \mathrm{OH}) \cdot{ }^{13} \mathrm{C}$ NMR $(500 \mathrm{MHz}$ DMSO $\left.\mathrm{d}_{6}\right), \delta_{\mathrm{c}} 53.08,102.61,115.15,112.78,115.79,120.66,126.66$, $126.23,129.24,130.05,130.13,133.70,157.94,161.14$, 162.87 .

\section{2-Amino-4-(3,4-dichlorophenyl)-7-hydroxy-4H- chromene-3-carbonitrile $4 \mathrm{~h}$}

IR: ( $\left.\mathrm{KBr} \mathrm{cm}^{-1}\right) 3478(\mathrm{OH}), 3342,3267\left(\mathrm{NH}_{2}\right), 3080$ (CH-Ar), 2933 (CH-Aliphatic), 2192 (CN), 1640 (C=C) 1467 (C=C), 1347 (C-N), 1154 (C-C), 1112 (C-O-C). H ${ }^{1}$ NMR (500 MHz DMSO - $\left.\mathrm{d}_{6}\right): \delta_{\mathrm{H}} 4.72(\mathrm{~s}, 1 \mathrm{H}, \mathrm{H}-4), 6.41(\mathrm{~d}, 1 \mathrm{H}, \mathrm{J}=2 \mathrm{~Hz}, \mathrm{Ar}-\mathrm{H})$, 6.49-6.51 (dd, $1 \mathrm{H}, J=2.5,6 \mathrm{~Hz}, \mathrm{Ar}-\mathrm{H}), 6.80(\mathrm{~d}, 1 \mathrm{H}, J=8.5 \mathrm{~Hz}$, Ar-H) $7.00\left(\mathrm{~s}, 2 \mathrm{H}, \mathrm{NH}_{2}\right.$ ), 7.13-7.15 (dd, $\left.1 \mathrm{H}, J=2,6.5 \mathrm{~Hz}, \mathrm{Ar}-\mathrm{H}\right)$, 7.43 (d, 1H, J= $2 \mathrm{~Hz}, \mathrm{Ar}-\mathrm{H}$ ), 7.5 (d, 1H, J= $8.5 \mathrm{~Hz}$ Ar-H), 9.80 (s, $1 \mathrm{H}, \mathrm{OH}) .{ }^{13} \mathrm{C}$ NMR (500 MHz DMSO d $), \delta_{c} 55.70,102.78$, $113.00,113.08,120.87,128.38,129.75,129.78,130.40$, $131.45,131.53,147.90,149.25,157.85,160.83$.

\section{2-Amino-4-(2,6-dichlorophenyl)-7-hydroxy-4H- chromene-3-carbonitrile $4 \mathrm{i}$}

IR: (KBr cm-1) $3481(\mathrm{OH}), 3339,3260\left(\mathrm{NH}_{2}\right), 3081(\mathrm{CH}-\mathrm{Ar})$, 2926 (CH-Aliphatic), 2190 (CN), 1641 (C=C) 1462 (C=C), 1339 (C-N), 1155 (C-C), 1112 (C-O-C). H1 NMR (500 MHz DMSO - $\left.\mathrm{d}_{6}\right): \delta_{\mathrm{H}} 5.69(\mathrm{~s}, 1 \mathrm{H}, \mathrm{H}-4), 6.37(\mathrm{~d}, 1 \mathrm{H}, J=2.5 \mathrm{~Hz}, \mathrm{Ar}-\mathrm{H})$, 6.45-6.47 (dd, 1H, J= 2.5, 6 Hz, Ar- H), 6.57 (d, 1H, J= 8.5, Ar- 
$\mathrm{H}), 6.93\left(\mathrm{~s}, 2 \mathrm{H}, \mathrm{NH}_{2}\right), 7.28-7.31(\mathrm{t}, 1 \mathrm{H}, J=8 \mathrm{~Hz}, \mathrm{Ar}-\mathrm{H}), 7.35(\mathrm{~d}$, $1 \mathrm{H}, J=7.5 \mathrm{~Hz}), 7.52(\mathrm{~d}, 1 \mathrm{H}, \mathrm{J}=8 \mathrm{~Hz}, \mathrm{Ar}-\mathrm{H}), 9.73(\mathrm{~s}, 1 \mathrm{H}, \mathrm{OH}) .{ }^{13} \mathrm{C}$ NMR (500 MHz DMSO d $)$ ), c $_{\mathrm{c}} 52.65,102.49,110.56,112.73$ $120.46,128.86,128.95,130.05,131.19,135.79,138.38$, $150.08,157.97,161.22$.

\section{2-Amino-4-(3-bromophenyl)-7-hydroxy-4H-chromene- 3-carbonitrile 4j}

IR: (KBr cm$\left.{ }^{-1}\right) 3435(\mathrm{OH}), 3338,3217\left(\mathrm{NH}_{2}\right), 3076(\mathrm{CH}-\mathrm{Ar})$, 2937 (CH-Aliphatic), 2194 (CN), 1649 (C=C) 1466 (C=C), 1317 (C-N), 1157 (C-C), 1114 (C-O-C). H1 NMR (500 MHz DMSO -d 6 ): $\delta_{\mathrm{H}} 4.68(\mathrm{~s}, 1 \mathrm{H}, \mathrm{H}-4), 6.4(\mathrm{~d}, 1 \mathrm{H}, J=2.4 \mathrm{~Hz}, \mathrm{Ar}-\mathrm{H})$ 6.49-6.52 (dd, 1H, J= 2.4, $6 \mathrm{~Hz}, \mathrm{Ar}-\mathrm{H}), 6.81(\mathrm{~d}, 1 \mathrm{H}, J=8.7 \mathrm{~Hz}$ ), $6.98\left(\mathrm{~s}, 2 \mathrm{H}, \mathrm{NH}_{2}\right), 7.17-7.20(\mathrm{~m}, 1 \mathrm{H}, \mathrm{Ar}-\mathrm{H}), 7.26-7.31(\mathrm{t}, 1 \mathrm{H}$, $J=7.8 \mathrm{~Hz}, \mathrm{Ar}-\mathrm{H}), 7.34-7.35(\mathrm{t}, 1 \mathrm{H}, J=1.8 \mathrm{~Hz}, \mathrm{Ar}-\mathrm{H}), 7.40-7.43$ (m, 1H, Ar-H), $9.77(\mathrm{~s}, 1 \mathrm{H}, \mathrm{OH}) \cdot{ }^{13} \mathrm{C}$ NMR (300 MHz DMSO $\left.\mathrm{d}_{6}\right), \delta_{\mathrm{c}} 55.64,1012.26,112.53,112.94,120.46,121.83$, $126.55,129.57,129.88,129.95,130.86,148.79,149.07$, $157.27,160.33$.

\section{2-Amino-4-(3-fluorophenyl)-7-hydroxy-4H-chromene-3- carbonitrile $4 \mathrm{k}$}

IR: (KBr cm-1) $3435(\mathrm{OH}), 3338,3217\left(\mathrm{NH}_{2}\right), 3076(\mathrm{CH}-\mathrm{Ar})$, 2937 (CH-Aliphatic), 2194 (CN), 1649 (C=C) 1466 (C=C), 1317 (C-N), 1157 (C-C), 1114 (C-O-C). H1 NMR (500 MHz DMSO - $\left.\mathrm{d}_{6}\right): \delta_{\mathrm{H}} 4.68(\mathrm{~s}, 1 \mathrm{H}, \mathrm{H}-4), 6.4(\mathrm{~d}, 1 \mathrm{H}, \mathrm{J}=2.4 \mathrm{~Hz}, \mathrm{Ar}-\mathrm{H})$ 6.49-6.52 (dd, 1H, J= 2.4, $6 \mathrm{~Hz}, \mathrm{Ar}-\mathrm{H}), 6.81(\mathrm{~d}, 1 \mathrm{H}, J=8.7 \mathrm{~Hz}$ ), $6.98\left(\mathrm{~s}, 2 \mathrm{H}, \mathrm{NH}_{2}\right), 7.17-7.20(\mathrm{~m}, 1 \mathrm{H}, \mathrm{Ar}-\mathrm{H}), 7.26-7.31(\mathrm{t}, 1 \mathrm{H}$, $J=7.8 \mathrm{~Hz}, \mathrm{Ar}-\mathrm{H}), 7.34-7.35(\mathrm{t}, 1 \mathrm{H}, J=1.8 \mathrm{~Hz}, \mathrm{Ar}-\mathrm{H}), 7.40-7.43$ (m, 1H, Ar-H), 9.77 (s, 1H, OH). ${ }^{13} \mathrm{C}$ NMR (300 MHz DMSO d6), $\delta_{c} 55.64,1012.26,112.53,112.94,120.46,121.83,126.55$, $129.57,129.88,129.95,130.86,148.79,149.07,157.27$, 160.33 .

\section{2-Amino-4-(2-fluorophenyl)-7-hydroxy-4H-chromene-3- carbonitrile 41}

IR: (KBr cm$\left.{ }^{-1}\right) 3423(\mathrm{OH}), 3332,3216\left(\mathrm{NH}_{2}\right), 3069$ (CH-Ar), 2904 (CH-Aliphatic), 2189 (CN), 1650 (C=C) 1453 (C=C), 1297 (C-N), 1148 (C-C), 1110 (C-O-C). H¹ NMR (300 MHz DMSO -d6): $\delta_{\mathrm{H}} 4.89$ (s, 1H, H-4), 6.40 (d, 1H, J= 2.4 Hz, Ar-H), 6.47-6.51 (dd, 1H, J= 2.4, $6 \mathrm{~Hz}, \mathrm{Ar}-\mathrm{H}), 6.77(\mathrm{~d}, 1 \mathrm{H}, J=8.4 \mathrm{~Hz}$, $\mathrm{Ar}-\mathrm{H}), 6.93$ (s, 2H, NH $\left.\mathrm{N}_{2}\right), 7.11-7.21(\mathrm{~m}, 3 \mathrm{H}, \mathrm{Ar}-\mathrm{H}), 7.23-7.31$ (m, 1H, Ar-H), 9.75 (s, 1H, OH), BC NMR (300 Hz DMSO d6) $\delta_{c} 54.62,102.22,112.42,115.58,115.80,124.65,128.73$, $129.45,129.79,132.50,149.07,157.24,158.24,160.59$, 161.49 .

\section{2-Amino-7-hydroxy-4-(3-methoxyphenyl)-4H- chromene-3-carbonitrile $4 \mathrm{~m}$}

IR: (KBr cm-1) $3418(\mathrm{OH}), 3335,3218\left(\mathrm{NH}_{2}\right), 3068$ (CH-Ar), 2943 (CH-Aliphatic), 2191 (CN), 1643 (C=C) 1460 (C=C), 1346 (C-N), 1152 (C-C), 1119 (C-O-C). H1 NMR (300 MHz DMSO - $\left.\mathrm{d}_{6}\right): \delta_{\mathrm{H}} 3.71\left(\mathrm{~s}, 3 \mathrm{H}, \mathrm{OCH}_{3}\right), 4.58(\mathrm{~s}, 1 \mathrm{H}, \mathrm{H}=4), 6.39(\mathrm{~d}$ $1 \mathrm{H}, J=2.4, \mathrm{Ar}-\mathrm{H}), 6.46-6.50(\mathrm{dd}, 1 \mathrm{H}, J=2.4,6 \mathrm{~Hz}, \mathrm{Ar}-\mathrm{H}), 6.70$ $7.73(\mathrm{t}, 2 \mathrm{H}, J=6.6 \mathrm{~Hz}, \mathrm{Ar}-\mathrm{H}), 6.76-6.79(\mathrm{~m}, 1 \mathrm{H}, \mathrm{Ar}-\mathrm{H}), 6.82(\mathrm{~d}$, $1 \mathrm{H}, J=8.4 \mathrm{~Hz}, \mathrm{Ar}-\mathrm{H}), 6.88\left(\mathrm{~s}, 2 \mathrm{H}, \mathrm{NH}_{2}\right.$ ), 7.19-7.24 (t, 1H, J=7.8, Ar-H), 9.71 (s, 1H, OH). ${ }^{13} \mathrm{C}$ NMR (300 MHz DMSO $\left.\mathrm{d}_{6}\right) \delta_{\mathrm{c}}$ 54.99, 56.21, 102.24, 111.53, 112.42, 113.54, 113.68, 119.64, $120.73,129.78,129.92,148.01,157.15,159.40,160.38$.

\section{2-Amino-4-(4-ethylphenyl)-7-hydroxy-4H-chromene-3- carbonitrile 4n}

IR: (KBr cm-1) $3481(\mathrm{OH}), 3345,3264\left(\mathrm{NH}_{2}\right), 3043$ (CH-Ar), 2967 (CH-Aliphatic), 2190 (CN), 1642 (C=C) 1461 (C=C), 1249 (C-N), 1154 (C-C), 1109 (C-O-C). H ${ }^{1}$ NMR (500 MHz DMSO - $\left.\mathrm{d}_{6}\right): \delta_{\mathrm{H}} 1.13\left(\mathrm{t}, 3 \mathrm{H}, J=7.5 \mathrm{~Hz} \mathrm{CH}_{3}\right), 2.52-2.57(\mathrm{q}, 2 \mathrm{H}$, $\left.J=7.5 \mathrm{~Hz} \mathrm{CH}_{3}\right) 2.52-2.57(\mathrm{q}, 2 \mathrm{H}, J=7.5 \mathrm{~Hz}, \mathrm{CH} 2), 4.57(\mathrm{~s}, 1 \mathrm{H}, \mathrm{H}-$ 4) $6.41(\mathrm{~s}, 1 \mathrm{H}, \mathrm{Ar}-\mathrm{H}), 6.47$ (d, 1H, J=8.5 Hz, Ar-H), 6.79 (d, 1H,
$J=8.5 \mathrm{~Hz}, \mathrm{Ar}-\mathrm{H}), 6.84\left(\mathrm{~s}, 2 \mathrm{H}, \mathrm{NH}_{2}\right), 7.06(\mathrm{~d}, 2 \mathrm{H}, J=8 \mathrm{~Hz}, \mathrm{Ar}-\mathrm{H})$, 7.12 (d, 2H, J=7.5 Hz, Ar-H), $9.68(\mathrm{~s}, 1 \mathrm{H}, \mathrm{OH}),{ }^{13} \mathrm{C}$ NMR (500 $\mathrm{MHz}$ DMSO d6) $\delta_{\mathrm{c}} 15.99,28.20,56.86,102.60,112.80$ $114.39,121.18,127.75,128.40,130.37,142.46,144.17$, $149.29,157.47,160.66$

\section{CONCLUSION}

In the present work, with a view of environmentally benign consciousness a new class of cyano amino benzopyrans has been accomplished in good to excellent yield in short reaction time under aqueous medium. The present protocol involves mild reaction condition, catalyst free cascade reaction and simple workup procedure. The structure of the hybrids of product were firmly established by IR, ${ }^{1} \mathrm{H}$ NMR, ${ }^{13} \mathrm{C}$ NMR, and single crystal X-Ray study.

\section{REFERENCES}

[1] Jaggavarapu SR, Kamalakaran AS, Nanubolu J, Jalli VP, Gangisetty SK, Gaddamanugu G, Synthesis of novel benzopyrano[3,2-c]coumarins via tandem base promoted nucleophilic substitution and intramolecular electrophilic aromatic cyclization, Tetrahedron Letters, 2014; 55:36703673.

[2] Pal R, Kumar V, Gupta AK, Beniwal V, Gupta GK, Synthesis, characterization, and DNA cleavage study of dehydroacetic acid based tridentate Schiff's base and its metal complexes of first transition series, Medicinal Chemistry Research, 2014;23:4060-4069.

[3] Zollinger H, Color Chemistry, Synthesis, Properties and Applications of Organic Dyes and Pigments, 3rd ed, VHCA, Zurikh, Switzerland, 2003.

[4] Bissell ER, Mitchell AR, Smith RE, Synthesis and chemistry of 7-amino-4-(trifluoromethyl)coumarin and its amino acid and peptide derivatives, The Journal of Organic Chemistry, 1980; 45:2283-2287.

[5] Ellis GP, In The Chemistry of Heterocyclic Compounds. Chromenes, Harmones, and Chromones; Weissberger A Taylor, E. C., Eds, John Wiley: New York, 1977; 11-139. Chapter II.

[6] Hafez EAA, Elnagdi MH, Elagamey AGA, El-Taweel FMAA, Nitriles in heterocyclic synthesis: novel synthesis of benzo[c]coumarin and of benzo[c]pyrano[3,2-c]quinoline derivatives, Heterocycles, 1987; 26(4):903-907.

[7] Hiramoto K, Nasuhara A, Michiloshi K, Kato T, Kikugawa K, DNA strand-breaking activity and mutagenicity of 2,3dihydro-3,5-dihydroxy-6-methyl-4H-pyran-4-one DDMP , a Maillard reaction product of glucose and glycine, Mutation Research, 1997; 395:47-56.

[8] Bianchi G, Tava A, Synthesis of (2R)(+)-2,3-dihydro-2,6dimethyl-4H-pyran-4-one, a homologue of pheromones of a species in the hepialidae family, Agricultural and Biological Chemistry, 1987; 51:2001-2002.

[9] Reynolds GA, Drexhage KH, New coumarin dyes with rigidized structure for flashlamp-pumped dye lasers, Optics Communication, 1975; 13:222-225.

[10] Anderson DR, Hegde S, Reinhard E, Gomez L, Vernier WF, Lee L, Liu S, Sambandam A, Snider PA, Masih L, Aminocyanopyridine inhibitors of mitogen activated protein kinase-activated protein kinase 2 (MK-2), Bioorganic \& Medicinal Chemistry Letters, 2005;15:1587-1590.

[11] Knight CG,Stephens T, Xanthene-dye-labelled phosphatidylethanolamines as probes of interfacial $\mathrm{pH}$. Studies in phospholipid vesicles, Biochemical Journal, 1989; 25: 8683-8685.

[12] Joulain D, Tabacchi R, Two volatile chromenes from Wisteria sinensis flowers, Phytochemistry, 1994; 37:1769-1770.

[13] Nolan KA, Zhao H, Faulder PF, Frenkel AD, Timson, DJ, Siegel D, Bryce R A, Coumarin-Based Inhibitors of Human NAD(P)H:Quinone Oxidoreductase-1. Identification, Structure-Activity, Off-Target Effects and In Vitro Human Pancreatic Cancer Toxicity. Journal of Medicinal Chemistry, 2007; 50(25): 6316-6325.

[14] Doshi J M, Tian D, \& Xing C, Structure-Activity Relationship Studies of Ethyl 2-Amino-6-bromo-4-(1-cyano-2-ethoxy-2oxoethyl)-4H-chromene-3-carboxylate (HA 14-1), an 
Antagonist for Antiapoptotic Bcl-2 Proteins To Overcome Drug Resistance in Cancer, Journal of Medicinal Chemistry, 2006; 49(26): 7731-7739.

[15] Kemnitzer W, Drewe J, Jiang S, Zhang H, Crogan-Grundy C, Labreque D, Cai S X, Discovery of 4-Aryl-4H-chromenes as a New Series of Apoptosis Inducers Using a Cell- and CaspaseBased High Throughput Screening Assay. 4. Structure-Activity Relationships of N-Alkyl Substituted Pyrrole Fused at the 7,8Positions, Journal of Medicinal Chemistry, 2008; 51(3): 417423.

[16] Rafinejad A, Fallah-Tafti A, Tiwari R, Shirazi AN, Mandal D, Shafiee A, Parang K, Foroumadi A, Akbarzadeh T (2012) 4Aryl-4Hnaphthopyrans derivatives: one-pot synthesis, evaluation of Src kinase inhibitory and anti-proliferative activities. DARU JouranlPharmaceuticalScience 20:100-106.

[17] Sabry NM, Mohamed HM, Khattab ESAEH, Motlaq SS, ElAgrodyAM, Synthesis of $4 \mathrm{H}$-chromene, coumarin, $12 \mathrm{H}$ chromeno[2,3-d]pyrimidine derivatives and some of their antimicrobial and cytotoxicity activities, European Journal Medicinal Chemistry,2011;(46) :765-772.

[18] Szulawska-Mroczek A, Szumilak M, Szczesio M, Olczak A Nazarski RB, Lewgowd W, Czyz M, Stanczak A Synthesis and biological evaluation of new bischromone derivatives with antiproliferative activity, Archieve Pharma Chemical Life Sciences,2013; (346):34-43.

[19] Zhang D, Ma Y, Liu Y, Liu ZP Synthesis of sulfonylhydrazoneand acylhydrazone-substituted 8-ethoxy-3-nitro2 Hchromenes as potent antiproliferative and apoptosis inducingagents,Archieve Pharma Chemical Life Sciences, 2014; 347:576-588.

[20] Ahmed M. Fouda ${ }^{1}$ Synthesis of several $4 \mathrm{H}$-chromene derivatives of expected

antitumor activity,Medicinal Chemistry Research, 2016; 25 (6), 1229-1238DOI 10.1007/s00044-016-1565-3.

[21] Musa MA, Badisa VLD, Latinwo LM, Waryoba C, Ugochukwu N In vitro cytotoxicity of benzopyranone derivatives with basic side chain against human lung cell lines,Anticancer research,2010; 30:4613-4617.

[22] Kheirollahi A, Pordeli M, Safavi M, Mashkouri S, Naimi-Jamal MR, Ardestani SK Cytotoxic and apoptotic affects of synthetic benzochromene derivatives on human cancer cell lines, Naunyn-Schmiedeberg'sArchieves Pharmacology,2014;387:1199-1208.

[23] Saffari Z, Aryapour H, Akbarzadeh A, Foroumadi A, Jafari N Zarabi MF, FarhangiA In vitro antitumor evaluation of 4Hchromene- 3-carbonitrile derivatives as a new series of apoptotic inducers, Tumor Biology,2014; 35:5845-5855.

[24] Patil SA, Patil R, Pfeffer LM, Miller DD Chromenes: potential new chemotherapeutic agents for cancer, Future Medicinal Chemistry, 2013;5:1647-1660.

[25] Patil SA, Patil R, Pfeffer LM, Miller DD Chromenes: potential new chemotherapeutic agents for cancer,Future Medicinal Chemistry,2013; 5:1647-1660

[26] Wiener C, Schroeder CH, West BD, Link KP Studies on the 4hydroxycoumarins. XVIII. 3-[a-(acetamidomethyl)benzyl]-4hydroxycoumarin and related products. Journal of Organic Chemistry,1962;27: 3086-3088.

[27] Kemnitzer W, Kasibhatla S, Jiang S, Zhang H, Zhao J, Jia S, Xu L, Crogan-Grundy C, Denis R, Barriault N, Vaillancourt L, Charron S, Dodd J, Attardo G, Labrecque D, Lamothe S, Gourdeau H, Tseng B, Drewe J, Cai SX Discovery of 4-aryl$4 \mathrm{Hchromenes}$ as a new series of apoptosis inducers using a cell- and caspase-based high-throughput screening assay. 2 . Structure activity relationships of the 7- and 5-, 6-, 8positions,Bioorganic Medicinal Chemistry Letters, 2005; 15:4745-4751

[28] Wang JL, Liu D, Zhang ZJ, Shan S, Han X, Srinivasula SM, Croce CM, Alnemri ES, Huang Z Structure-based discovery of an organic compound that binds $\mathrm{Bcl}-2$ protein and induces apoptosis of tumor cells,Proceedings of the National Academy of Sciences of the United States of America, 2000; 97:71247129.

[29] Saeedi M, Mahdavi M, Foroumadi A, Shafiee A Synthesis of novel fused 4,5-dihydro-1,2,3-triazolo[1,5a] $[1,4]$ benzodiazepine derivatives via four-component UgiSmiles-type reaction, Tetrahedron,2013;69:3506-3510.

[30] Hosseini-Zare MS, Mahdavi M, Saeedi M, Asadi M, Javanshir S, Shafiee A, Foroumadi A Synthesis of 2,3-diaryl5Himidazo[2,1-a]isoindol-5-ones via the one-pot reaction of 1,2-diketones, 2-formylbenzoic acids, and ammonium acetate, Tetrahedron Letters,2012;53:3448-3451.

[31] Akbarzadeh T, Rafinejad A, Malekian Mollaghasem J, Safavi M, Fallah-Tafti A, Pordeli M, Kabudanian Ardestani S, Shafiee A, Foroumadi A, 2-Amino-3-cyano-4-(5-arylisoxazol-3-yl)-4Hchromenes: synthesis and in vitro cytotoxic activity, Arch Pharm 2012; 345:386-392

[32] Thomas N, Zachariah SM In Silico drug design and analysis of 4-Phenyl-4H-chromene derivatives as anticancer and antiinflammatory agents,International Journal of Pharmaceutical Sciences Review and Research, 2013;22:50-54.

[33] Magedov IV, Manpadi M, Evdokimov NM, Elias EM, Rozhkova E, Ogasawara MA, Bettale JD, Przheval'skii NM, Rogelj S, Kornienko A Antiproliferative and apoptosis inducingproperties of pyrano[3,2-c]pyridones accessible by a one-step multicomponent synthesis, Bioorganic Medicinal Chemistry Letters,2007;17:3872-3876.

[34] Singh OM, Devi NS, Thokchom DS, Sharma GJ (2010) Novel 3 alkanoyl/aroyl/-heteroaroyl-2H-chromene-2-thiones: synthesis and evaluation of their antioxidant activities,European Journal of Medicinal Chemistry,2014; 5:2250-2257.

[35] Bhat M, Siddiqui N, Khan S (2008) Synthesis of novel 3-(4acetyl- $5 \mathrm{H} /$ methyl-5-substituted phenyl-4,5-dihydro-1,3,4oxadiazol-2-yl)-2H-chromen-2-ones as potential anticonvulsant agents,ActaPoloniaePharmaceutica - Drug Research65:235-239

[36] Nimesh RK, Dhaval DH, Prashant TM, Saurabh KP Synthesis and evaluation of in vitro antitubercular activity and antimicrobial activity of some novel 4H-chromeno[2,3d]pyrimi-dine via 2-Amino-4-phenyl-4H-chromene-3carbonitriles, Medicinal Chemistry Research,2011;20:854864

[37] Nareshkumar J, Jiayi X, Ramesh MK, Fuyong D, Guo JZ, Emmanuel $\mathrm{P}$ Identification and structure-activity relationships of chromene-derived selective estrogen receptor modulators fortreatment of postmenopausal symptoms, Journalof Medicinal Chemistry,2009; 52: 75447569

[38] Cheng JF, Ishikawa A, Ono Y, Arrhenius T, Nadzan A Novel chromenederivatives as TNF-a inhibitors,Bioorganic Medicinal Chemistry Letters,2003;13:3647-3650

[39] Birch KA, Heath WF, Hermeling RN, Johnston CM, Stramm L, Dell C, Smith C, Williamson JR, Reifel-Miller A LY290181, an inhibitor of diabetes induced vascular dysfunction, blocks protein kinase C-stimulated transcriptional activation through inhibition of transcription factor binding to a phorbol response element, Diabetes, 1996; 45:642-650

[40] Thompson LA Recent applications of polymer-supported reagents and scavengers in combinatorial, parallel, or multistep synthesis, Current Opinion in Chemical biology, 20004:324-337

[41] Kumar D, Sharma P, Singh H, Nepali K, Gupta GK, Jain SK, \& Ntie-Kang $F$, The value of pyrans as anticancer scaffolds in medicinal chemistry, Royal Society of Chemistry Advances, 2017; 7(59): 36977-36999. 